\title{
La revista Andamios: apertura, voces divergentes y pluralidad máxima*
}

\section{The Andamios magazine: opening, differing voices and maximum plurality}

\author{
Begoña Alberdi \\ Facultad de Letras, Pontificia Universidad Católica de Chile, Chile \\ alberdi@uc.cl
}

Resumen - El objeto de estudio del presente trabajo es la revista Andamios, creada en 1925 por la Asociación General de Profesores, como cuerpo de difusión de las primeras manifestaciones de la vanguardia chilena. La revista se estudiará mediante un análisis de su diagramación y de su discurso escrito y visual, lo que permitirá articular, desde distintas aristas, la propuesta ideológico-estética del grupo. Con ello se busca describir la principal contribución de Andamios al proceso de autonomización del campo literario y artístico chileno y asimismo dar cuenta del posicionamiento de las vanguardias en Chile en la década de los veinte.

Palabras clave: vanguardia chilena, revistas, campo cultural, apropiación.

\begin{abstract}
This essay focuses on the Andamios magazine, created in 1925 by the Asociación General de Profesores, intended to disseminate the first expressions of the Chilean avant-garde. The magazine, as an object of study, will be studied through the analysis of its layout, as well as its writing and visual content. This will allow an articulation, from a variety of angles, of the group's ideological and aesthetical proposal. This essay will describe and contextualize the contribution of Andamios to the independent development of the Chilean's artistic and literary field. It will also give account of the positioning of the avant-garde in Chile in the twenties.
\end{abstract}

Key words: Chilean avant-garde; magazines; cultural field; appropriation.

* Este trabajo forma parte del proyecto Fondecyt $\mathrm{N}^{\circ} 1090735$, «La vanguardia chilena en sus revistas (1920-1930): modernidad, poesía e intelectuales», dirigido por Patricio Lizama A., de la Pontificia Universidad Católica de Chile. 
254

AISTHESIS No 50 (2011): 253-274

\section{INTRODUCCIÓN}

\section{LA LABOR DE LAS REVISTAS EN EL CONTEXTO DE VANGUARDIA}

Las revistas literarias y culturales son «[...] imprescindibles para leer y redactar la historia literaria latinoamericana del siglo XX» (Sosnowski, 11). En el contexto de las vanguardias de principios de siglo, dichas revistas cumplen un rol fundamental, pues constituyen un espacio propicio para llevar a cabo la adaptación e incorporación de los ismos europeos. Así, en el caso de Chile y América Latina, las revistas de vanguardia funcionan como verdaderos «nichos de apropiación» (Subercaseaux, 70) que interiorizan paradigmas culturales provenientes de Europa y dialogan con ellos como si les fueran propios, con lo cual se instalan en un eje de doble cruce: por una parte entre los paradigmas externos y los propios y, por otra, entre el resultado de ese primer cruce y su difusión al público nacional, que funciona como sistema de control y caja de resonancia (Moraña, 239) de las nuevas propuestas.

Del sinnúmero de revistas y formaciones ${ }^{1}$ fugaces instaladas en la década de los veinte en el país - Juventud, Claridad, Ariel, Dínamo, Dyonisios, Andarivel, Nguillatún, Agonal, Panorama, etc.- - el presente trabajo se centrará en la revista Andamios, suplemento del periódico Nuevos Rumbos, creado por la Asociación General de Profesores (AGP) como cuerpo de difusión, en el ámbito de la creación, de las primeras manifestaciones de la vanguardia chilena y, por ende, abierto al espíritu nuevo de cambio y renovación cultural.

La revista Andamios, cuyo director fue Salvador Fuentes Vega, apareció por primera vez en 1925, momento en que se publicaron sus dos únicos números. Ese mismo año se incorpora como codirector Pablo Neruda y aparece un tercer y único número de la revista Caballo de Bastos (ex Andamios).

En el marco de la recepción y adaptación de un discurso de modernidad ajeno, la labor específica de la AGP adquiere una gran importancia, no porque haya conformado las bases programáticas de la vanguardia, sino principalmente porque difundió, en diversos lugares, las primeras manifestaciones vanguardistas: «[...] tanto por el extenso campo que cubrió como por el conglomerado que produjo respecto a actores, sedes, actos y discusiones que propició el ‘arte nuevo〉 resultó un momento clave en la difusión que las vanguardias alcanzaron en Chile [...]» (Santos, 149). Con ello, Andamios hace visible un tema de conflictividad social, como es el enfrentamiento entre el arte nuevo y los sistemas de representación y legitimación vigentes, además de lo cual, al cuestionar la naturaleza, función y sentido del arte, sienta las bases para la posterior consolidación de las vanguardias en la década de los treinta.

Es así como el estudio de Andamios y de la AGP resulta de suma importancia para reconstruir la labor de aquellas instituciones y formaciones que cumplieron un papel fundamental en el proceso de mediación y apropiación de los movimientos de vanguardia surgidos en Europa. El análisis de dicha revista busca perfilar al grupo Andamios como

Las formaciones son definidas por Pierre Bourdieu como agrupaciones intelectuales con un número reducido de miembros, sin reglas y de carácter laxo (Altamirano y Sarlo). 
un «acontecimiento cultural» que logró configurarse como un espacio particular dentro de las múltiples revistas surgidas en la década de los veinte; un espacio organizador de discursos que posibilitó tanto la generación de opiniones — estéticas, ideológicas y literarias - como el posicionamiento de un grupo y su contribución al proceso de autonomización del campo literario y artístico ${ }^{2}$ chileno.

\section{LA AGP Y LA GESTACIÓN DE LA REVISTA ANDAMIOS}

La Asociación General de Profesores de Chile es el primer ejemplo de organización sindical docente y uno de los grandes actores colectivos de la historia reciente del país. Se extendió desde 1923 a 1928, dentro del proceso de ascenso e irrupción de las clases medias, como un movimiento político, ideológico y cultural de amplias dimensiones, cuyo objetivo principal fue una reforma en conjunto del sistema educacional. Para ello, la Asociación contaba con estrategias distintivas de difusión, tales como el establecimiento de relaciones estrechas con el campo obrero y la fundación de «hogares sociales» en diferentes ciudades, en los que se realizaban veladas culturales. Esa labor se refuerza con la publicación de un periódico, Nuevos Rumbos ${ }^{3}$, que constituyó el principal instrumento de difusión del quehacer de las agrupaciones departamentales y de las múltiples actividades culturales organizadas por la AGP a lo largo de todo el país.

Por otra parte, la Asociación creó un clima estimulante para que los profesores desarrollaran sus capacidades creativas, y el talento literario de algunos de ellos- como Humberto Díaz Casanueva, Gerardo Seguel y Carlos Sepúlveda Leyton- trascendió más allá de la AGP. Además, el movimiento fue un significativo foro de discusión y difusión de ideas filosóficas y de conocimiento científico, así como un estímulo al estudio y la lectura - con la creación de bibliotecas y un fomento a la circulación de obras artísticas, ideológicas y pedagógicas ${ }^{4}$. Esa riqueza de la actividad literaria y estética es la que lleva a la formación de un suplemento cultural destinado exclusivamente a la difusión, en el ámbito de la creación, de las primeras manifestaciones de vanguardia: la revista Andamios y luego Caballo de Bastos.

Es necesario recalcar que la Asociación «[...] tuvo como objetivo básico una reforma global del sistema educativo. Por estas ideas de avanzada que involucraban una renovación integral de la persona y de la cultura, la AGP y su órgano Nuevos Rumbos se constituyó en un agente colectivo indirecto de la difusión del arte nuevo» (Santos, 151). A pesar de que la difusión de vanguardias sea un aspecto colateral dentro de la reforma educacional, la labor de la AGP resulta fundamental para la posterior consolidación de ellas en la década de los treinta, debido al alto alcance que tuvo la divulgación de sus primeras manifestaciones.

2 Pierre Bourdieu denomina campo intelectual al «[...] universo sometido a sus propias leyes de funcionamiento y de transformación, es decir la estructura de las relaciones objetivas entre la posición que en él ocupan individuos o grupos situados en situación de competencia por la legitimidad [...]» (318).

Periódico quincenal que circuló entre los años 1923 y 1926 (65 números en total).

4 La recolección de obras se logra en gran parte gracias a la ayuda de los mismos lectores de la revista. En ella se lee, «¿Es Ud. autor que viva en el día de hoy? ¿Puede obsequiar un libro de arte nuevo? Ayúdenos al ‘Grupo Andamios`, esté Ud. donde esté. Se le agradecerá. Tendremos un saloncito de charla y lectura para toda persona que no solo parezca sino que sea joven» (Andamios 2,8). 
Por último, la adscripción al «arte nuevo» que promulga la Asociación va unida a la disputa entre tradición y modernidad, que enfrenta a un orden oligárquico en decadencia con los nuevos grupos medios. Que la AGP incorpore en su plan de reforma tanto aspectos político-ideológicos como de la vanguardia artística es un reflejo de su interés por enfrentar al poder dominante en todas sus manifestaciones y por generar una diferenciación entre el orden cultural y el político, para lo cual «[...] lanzaban el desafío de crear belleza), y de gestar una nueva sensibilidad con formas, voces e imágenes originales $»^{5}$ (Lizama, 18).

\section{ANÁLISIS DEL OBJETO-REVISTA}

\section{MORFOGRAMA Y DIAGRAMACIÓN}

La presentación visual de las palabras, distribuidas en el espacio bidimensional de la página, y su combinación con otros signos no son en modo alguno una práctica arbitraria. Un libro no es un mero artefacto lingüístico, sino una compleja «máquina visual» (Abril, 107), donde los elementos cobran un valor según su disposición en la superficie. Desde esa perspectiva, un análisis del morfograma y diagramación de un texto no tomará en cuenta el significado de sus contenidos, sino el modo en que ellos se escriben y distribuyen sobre la página. Así, la diagramación permitirá revelar aquellas características del texto, en este caso la revista Andamios, que lo vuelven significante y valioso en cuanto objeto tangible ${ }^{6}$.

En relación a esto último, la distribución de los contenidos de Andamios responderá principalmente a dos elementos: la lógica estructural del collage y la tipografía libre. Siguiendo a Bürger, podemos decir que la técnica del collage consiste, en pintura, en la incorporación de fragmentos de realidad al interior de la superficie pictórica, procedimiento que termina por destruir el principio de unidad de la obra de arte, lo que rompe con su carácter orgánico y genera obras fragmentadas e irresueltas, «[...] que ya no provocan la apariencia de reconciliación» (142).

De ese modo, la revista Andamios es, desde su diagramación, un objeto inorgánico, en cuanto niega una síntesis de sus contenidos y los expone como fragmentos independientes que evidencian, en su yuxtaposición y discontinuidad, los procedimientos de escritura, selección y elaboración que darán origen al objeto-revista.

Es así como el principio del «cortar y pegar» se hace presente desde las portadas de Andamios, cuyo título, escrito a mano y con una tipografía infantil, contrasta con el

\footnotetext{
Esto último es parte de lo que defiende Andamios en su manifiesto, publicado en el número 37 del periódico Nuevos Rumbos, en el que se proclama el fin de una época en decadencia y el comienzo de una época nueva, que trae consigo la gestación de una nueva belleza.

6 Ese tipo de estudio se denomina bibliología: «Bibliography is the study of books as tangible objects. It examines the materials of which they are made and the manner in which those materials are put together [...] It is not concerned with their contents in a literary sense, but it is certainly concerned with the signs and symbols they contain (apart from their significance) for the manner in which these marks are written or impressed is a very relevant bibliographical fact» (Harris, 4).
} 
resto de la composición tipográfica hecha a máquina. La connotación de ese peritexto editorial ${ }^{7}$ es fundamental, pues entrega las claves para entender tanto el tipo de arte que se difundirá al interior de sus páginas — un arte espontáneo y expresivo cercano al de los niños-, como la ausencia de preceptos en la elaboración de la misma revista, lo que lleva a que cada una de sus publicaciones sea distinta a la otra.

En las páginas interiores de la revista, los elementos se disponen sobre la superficie a modo de collage. Así, textos, secciones e imágenes conforman piezas autónomas y discontinuas, tanto por una disparidad en sus contenidos como por la ausencia de un discurso unificador entre ellos. Andamios propaga así un espacio de libertad para el arte, que se extiende consecuentemente desde su misma configuración como revista, ya que la ausencia de un hilo conductor o discurso unificador entre los distintos fragmentos que allí aparecen, se corresponde a su vez con la ausencia de una homogeneidad formal, que se refleja en el uso de una tipografía libre prácticamente en cada uno de los fragmentos (sobre todo en los títulos) ${ }^{8}$.

De ese modo, la reorganización del material y la conciencia de la página como un espacio de composición dinámico es un aspecto fundamental para comprender la diagramación de la revista. En ella, los poemas se disponen uno al lado del otro, en distinta fuente y tamaño, junto a fragmentos como «Otra masacre», «Índice del momento» o «La inquietud chilena», que se refieren a la situación sociopolítica del país. Esa heterogeneidad se lleva a un extremo en la sección «Puzzle», conformada por pequeños enunciados completamente independientes unos de otros:

No le hagan caso a Eugenio Noel/ Dínamo aparecerá esta semana. Léalo usted. / Pronto Pronto. Exposición de arte infantil en el local de la Asociación de Profesores Primarios: Rosas 1022/ Francisco Villaespesa no existe. Es una invención de las chiquillas y de los modelos románticos. Los versos de ese hombre los escribió Pedro Sienna/ Pablo Neruda se va para Europa en diez días más (Andamios 1,10).

Luego, en el segundo número de la revista, el título «Puzzle» desaparece, con lo que aumenta la dificultad para el lector, quien debe realizar un trabajo de reconstrucción textual mucho mayor, a partir de piezas sueltas tituladas "Ventana», "Caja de fósforos» y «Run-Run», títulos metafóricos y no ya descriptivos como el anterior «Puzzle». Así, la marca de fragmentación se presenta indirectamente mediante tipografías completamente distintas en fuente y tamaño, que hacen visible en el plano de la expresión, una discontinuidad en el plano del contenido.

Esa nueva lógica del collage impulsada por Andamios conlleva un cambio radical en el modo de mirar del lector, el que será explicitado al interior de la misma revista con el caligrama «Paysage» de Vicente Huidobro ${ }^{9}$. Ese tipo de poesía visual funcionará como una clave de lectura para todo el cuerpo de la revista, ya que ambos textos deben ser leídos simultáneamente como un todo, y no desde una lógica lineal. Collage y caligrama

Gérard Genette llama peritexto editorial a toda la zona que se encuentra bajo la responsabilidad directa del editor. Es el peritexto más exterior, es decir, la portada, portadilla y anexos. Comprende a la realización material del libro: formato, papel, composición tipográfica (19).

8 Esta tipografía desatada se enmarca dentro de la revolución tipográfica encabezada por Marinetti en los años veinte. Las parole in libertà rompieron con la armonía de la página mediante el uso de distintos colores de tinta y más de veinte fuentes tipográficas que permitían dotar a las palabras de una expresividad inusitada (Cundy).

9 El caligrama de Huidobro y el concepto de «poesía visual» serán estudiados más adelante. 
surgen como tales, sólo si sus partes son leídas como un conjunto textual sincrónico. Desde esa perspectiva, ambos se insertan dentro de la lógica del «espacio sinóptico»:

[...] forma cultural y cognitiva del espacio tipográfico [...] Al hablar de sinóptico (de sinopsis: examen de conjunto, ver a la vez de una ojeada) trato de aludir con mayor precisión a una forma de experiencia visual, la visión sincrónica de un conjunto textual que no era posible con los discursos temporalizados de la narración y la oratoria (Abril, 109).

Andamios es, de ese modo, un espacio sinóptico regido por la lógica estructural del collage y la tipografía libre, que hacen de la página un espacio de composición dinámico y heterogéneo, que transparenta el carácter de mediación de la revista. El hecho de que los distintos poemas e imágenes guarden una diferenciación formal, bien tipográfica, bien de disposición sobre la página, además de la ausencia de un discurso que los unifique, acentúa el objetivo de Andamios — proclamado en su manifiesto- de ser un espacio completamente libre para la difusión del arte nuevo. La revista busca expresar, mediante su diagramación, que su función no es crear sino recoger; de ahí que imágenes y poemas parezcan "papeles encontrados» que fueron luego pegados en sus páginas.

Finalmente, y en el contexto de introducción de las vanguardias en el que se inserta el grupo Andamios, es necesario preguntarse cómo fue preparado el público por la institución arte para llegar a acoger obras que apenas habían creado su propio horizonte de lectores (Vergara, 30). Andamios lleva a cabo dicha labor mediante dos mecanismos: primero la difusión de las manifestaciones artísticas que componen la vanguardia; y segundo la morfología misma de la revista, que requiere para ser leída un acercamiento distinto hacia sus páginas, sinópticas y fragmentadas. Esto último resulta fundamental para la preparación del público, quien obtiene las claves para la comprensión del nuevo arte a través de la morfología misma de la revista que lo presenta.

\section{DISCURSO VISUAL}

La configuración de Andamios como collage y la estructuración autónoma de cada una de sus partes determinan la imposibilidad de visualizar cada página de la revista como un juego compositivo jerarquizado. En la revista no existe una valoración de los elementos según su emplazamiento, sino una igualdad jerárquica entre imágenes, textos, formas y espacios que, situados bajo la lógica del «espacio sinóptico", exigen del receptor tanto una visión sincrónica del conjunto textual, como una lectura autónoma de cada una de las partes que lo conforman.

De ese modo, la revista es el resultado de elementos independientes que se reúnen y se ponen sobre la página, sin perder la autonomía y clausura que los caracteriza como textos. Bajo la misma lógica, las imágenes al interior de Andamios no funcionan como ilustraciones o elementos paratextuales, es decir, como acompañamiento decorativo o aclaratorio del texto escrito, sino como un texto en sí mismo, que requiere ser leído como tal.

Las obras que se difunden en Andamios provienen en su mayoría de los artistas del grupo Montparnasse, Julio y Manuel Ortiz de Zárate, Luis Vargas Rosas y posteriormente Pablo Vidor. El retorno de dicho grupo al país hizo florecer un espíritu de cambio, 
con una nueva manera de concebir el arte, que se intentará cristalizar en las páginas de Andamios. Además de ese grupo, en la revista se difunden obras de artistas menos reconocidos, como Oskar Brazda, pintor checo relacionado con el expresionismo alemán, y Federico Ricci Sánchez, amigo del liceo de Temuco de Neruda.

La lectura interpretativa de las imágenes de los artistas es propiciada en la revista gracias a la ausencia casi total de referencias; las imágenes no tienen título ni año y solamente se indica el autor y la técnica, lo cual obliga al lector a realizar una lectura no analógica, es decir, que no esté basada en el reconocimiento de los objetos del mundo real sobre la superficie de la obra. Así, la sola presentación de las imágenes de Andamios, completamente libres de título, comentarios y análisis críticos, permite, en palabras de Emar, que las obras no estén limitadas por el fatídico ejercicio del nombrar (159).

Así entonces, las imágenes de Andamios serán leídas como vehículos seleccionados de la memoria cultural (Warburg, El Renacimiento, 33); es decir, como imágenes que se configuran a partir de la migración de referencias visuales. En ese sentido, la obra de arte se entiende como, «[...] resultado de una transmisión histórica que se presentaba frecuentemente en modo discontinuo y heterogéneo, abandonando así el ideal estético de una entidad estática armoniosamente autónoma» (36).

El término «viaje de las imágenes» ${ }^{10}$ posibilita, en el contexto de las vanguardias de América Latina, la visualización y comprensión de aquellos elementos de los ismos europeos que son incorporados y adaptados para la configuración de una vanguardia propiamente latinoamericana. De ese modo, la concepción de la imagen como producto de una migración de referencias visuales permite hacer visible el modo en que los artistas, agentes activos en el proceso de la migración, seleccionan e interiorizan distintos paradigmas culturales para la creación de sus imágenes.

En relación a esto último, la autonomía de dichas imágenes-texto y su lectura como producto de la migración de referencias visuales se llevará a cabo teniendo en cuenta las siguientes preguntas: ¿cuáles son las imágenes, poses, gestos y estilos que seleccionan los artistas latinoamericanos de las vanguardias europeas? y ¿qué transformación sufren esos modelos de referencia en el traslado?

En primer lugar, la obra de Oskar Brazda se afirma en la tensión entre clasicismo y primitivismo que caracteriza a los primeros años de la vanguardia en Europa. Desde esa tensión, dos referencias visuales se trasladan y encuentran en su obra: Gauguin, como cara visible del primitivismo, e Ingres y Hannecker, como representantes indiscutibles del clasicismo del siglo XIX.

$\overline{10}$ Término acuñado por Aby Warburg para el estudio de la supervivencia de lo antiguo en el Renacimiento. 


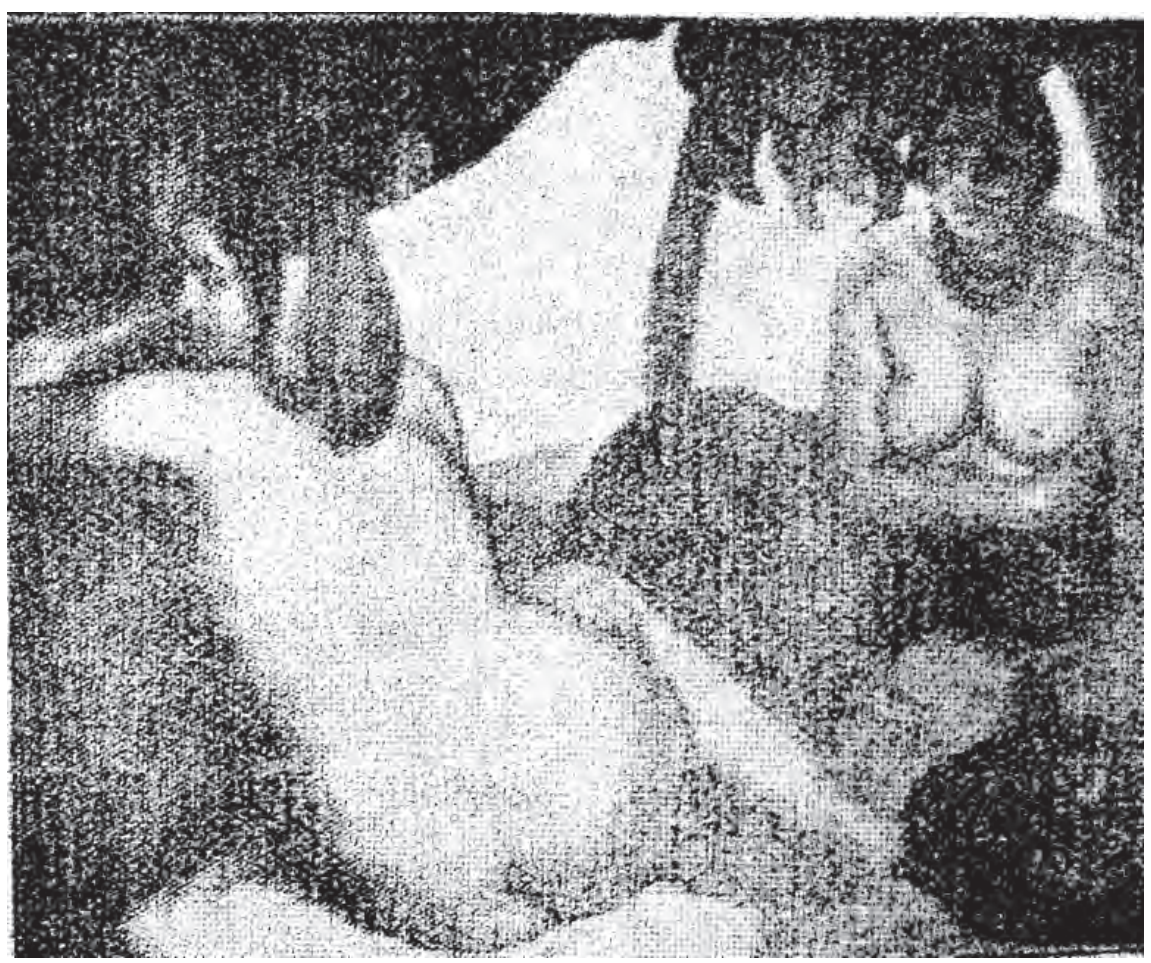

Oskar Brazda. Sin título. n.d. Andamios 2.

Por una parte, Gauguin es el símbolo del espíritu salvaje que se sitúa frente a una civilización industrial y urbana (Bozal, 123). El artista francés es tomado por Brazda a partir de una anécdota que podría calificarse como primitiva: la mujer tahitiana y la naturaleza, pero que no es primitiva en lo absoluto en cuanto a la pose de sus figuras. La monumentalidad de la pose de la mujer de espaldas proviene del clasicismo, «[...] que se debe tanto al ritmo de su disposición como a la simplicidad e intemporalidad de la que hacen gala» (127). Así, mientras la figuración de los torsos sigue la línea de Ingres - pureza en las formas, líneas sinuosas - la pose es muy similar a la Ariadne de Hannecker, una de las esculturas más importantes del siglo XIX, y por ende, posible referencia visual de la imagen de Brazda. Por su parte la figura de Ingres se hace presente en el contexto de vanguardia gracias a la obra de ciertos autores, como el surrealista Man Ray, quien retoma los torsos femeninos de Ingres y los inserta en un nuevo contexto.

La tensión clasicista-primitivista es, sin embargo, homogeneizada en el espacio bidimensional de la imagen, en el que las figuras están trabajadas como masas cromáticas aplanadas; así, fondo y figura se sitúan en un mismo plano, lo que incide en que la anécdota no sea el elemento principal de la obra. Esa inversión - la que pone al lenguaje artístico sobre el tema - permite la reflexión sobre la condición misma de la pintura; «[...] sobre sus límites y sus posibilidades, la reflexión sobre el plano pictórico y el volumen escultórico, sobre los elementos propios de un arte y otro, sus valores semánticos, su capacidad» (Bozal, 23). 
Ahora bien, el primitivismo de Brazda, y por consiguiente el de Gauguin, se insertan dentro del culto a lo nuevo, producto del hallazgo de las culturas marginales y primitivas, que, en palabras de Bozal, "prescinde[n] de la elaboración lingüística que la historia del clasicismo ha desarrollado [...]» (37). Sin embargo, en la obra de ambos artistas lo primitivo aparece figurado desde una gestualidad clásica, pues sólo a través de ese arte las figuras primitivas adquieren una monumentalidad que las hace perdurables.

En el contexto chileno de vanguardia, el gesto de incluir dicha imagen apunta a un deseo por redescubrir el mundo precolombino, traerlo hacia la modernidad e inmortalizarlo en ella, con lo cual se intenta abarcar «[...] el abanico entero de la temporalidad» (Paz, 21), lo que trae como consecuencia una simultaneidad de tiempos y presencias que rompe con el pasado inmediato para remitir al más antiguo. Es interesante que en Andamios la inserción del primitivismo se realice con la imagen de un pintor checo que representa una cultura primitiva foránea, pues se remite sólo indirectamente a la problemática indígena; en otras palabras, la propia identidad se afirma desde una lejanía, y, por ende, la mezcla entre «lo adquirido» y «lo propio» (Bosi, 20) que caracteriza a las vanguardias latinoamericanas se lleva a cabo de manera conflictiva en el caso de Chile.

En cuanto a la obra de Luis Vargas Rosas, la migración de imágenes puede resumirse desde dos grandes sistemas de referencias visuales: el primero el fauvismo ${ }^{11}$, sintetizado en la figura de Matisse, y el segundo, las estampas japonesas de grabados en madera.

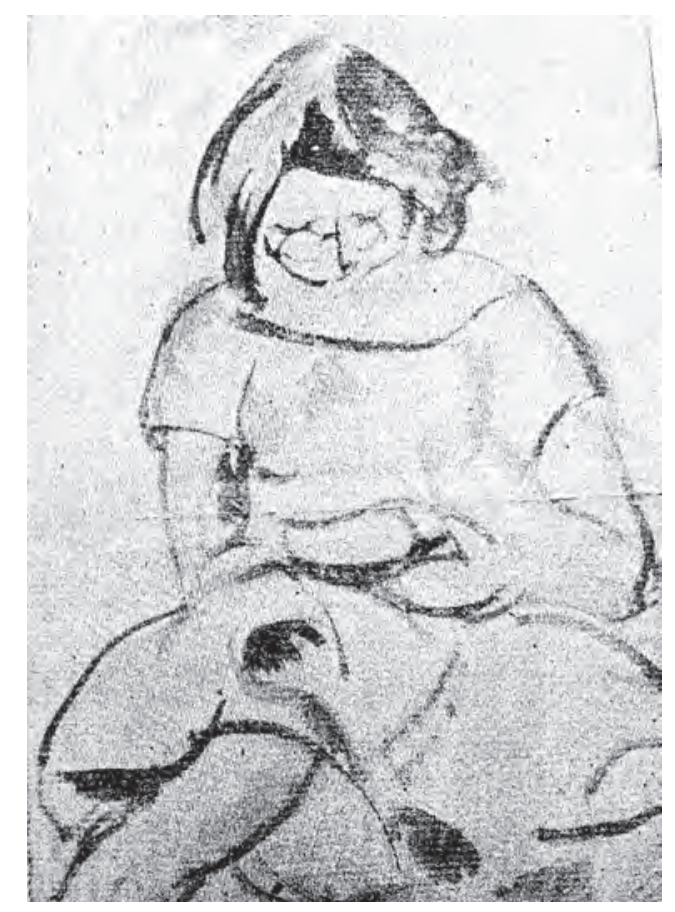

Luis Vargas Rosas. Sin título. n.d. Andamios 1.

11 Movimiento pictórico francés originado entre 1905 y 1908 aproximadamente (Elderfield). 
En primer lugar, el «viaje de imágenes» desde el mundo de los fauves se observa en el dibujo a partir de una radical simplificación del tema y de las referencias espacio-temporales. En la imagen se presenta la figura de una mujer sentada sobre un fondo vacío, escasamente caracterizada y sintetizada a partir del contorno; del mismo modo, tanto La linea verde de Matisse como Mujer delante de la ventana son imágenes concentradas, que hacen visible únicamente al sujeto y dejan de lado lo que está alrededor de él. El espíritu de síntesis de la línea suelta de Matisse se hace presente en este autor con la utilización de la misma «violencia lineal» (Bozal, 87) del artista francés. Más allá de la similitud en la anécdota, lo que permite leer el dibujo de Vargas Rosas como un vehículo de transmisión histórica de la representación visual de los fauves es la concepción de la imagen como una reproducción inexacta del mundo real. Dicha inexactitud reside en aquellos elementos que no pueden calificarse como formantes figurativos ${ }^{12}$ y que irrumpen como mero elemento plástico, ajeno a un sistema de representación icónico, como la línea verde sobre el rostro de Madame Matisse o la mancha sobre la cabeza y cuerpo de la mujer de Vargas Rosas, lo que da cuenta de una tensión entre un sistema de representación mimético, cuyo lenguaje sirve para dar cuenta del mundo natural, y otro meramente plástico, que experimenta con su propia materialidad. Finalmente, el principio de síntesis presente en ambas imágenes se lleva a cabo por una línea suelta; expresiva y a la vez sintética, que conlleva un trabajo de precisión y economía que revela tras de sí un nuevo concepto de belleza.

En segundo lugar, en el dibujo de Vargas Rosas el traslado de referencias japonesas ${ }^{13}$ se observa principalmente en tres aspectos: en el abandono de la perspectiva tridimensional en favor de planos bidimensionales con unidades cromáticas definidas, en la elección de un tema delicado - principalmente el mundo femenino-, y sobre todo en el empleo de una línea que emula, al mismo tiempo, la técnica de los japoneses en sus dibujos en tinta y la soltura lineal de Matisse.

La incorporación de nuevos modos de representación en su obra responde a la necesidad de crear nuevos lenguajes que, alejados de su función mimética, rompan la separación entre arte y vida e incluyan al arte dentro de una «praxis vital» (Bürger, 103); este abrir el arte a la vida es un principio que el mismo grupo Andamios expresa en su revista a través de la difusión y defensa del arte infantil ${ }^{14}$. La espontaneidad de ese tipo de arte propagado por Andamios busca introducir una modificación dentro del campo cultural, pues al proclamar un arte libre y vivo, quebranta a un arte oficial que se funda y sostiene únicamente sobre preceptos.

Por otra parte, la migración de referencias visuales al interior de Andamios se ve expandida con la figura del pintor de origen húngaro Pablo Vidor, autor de la mayor parte de las imágenes del número tres de la revista, que responden, cada una de ellas, a diferentes paradigmas visuales: Cézanne, el expresionismo alemán, Modigliani y el clasicismo. La primera migración visual en la obra de Vidor retoma el espíritu constructivista de Cézanne.

12 A. J. Greimas llama formante figurativo al conjunto de trazos que permiten, de manera pertinente, su identificación con un objeto del mundo natural mediante un proceso de aprehensión simultánea.

13 La migración de referencias visuales desde Japón se explica por la apertura comercial de ese país a mediados del siglo XIX, lo que trajo consigo un interés generalizado en Europa por el arte japonés (Read, 24).

14 Esta defensa tiene como origen una revolucionaria exposición organizada por Julio Ortiz de Zárate, quien convocó a los niños a que enviasen sus dibujos y pinturas a través de las Notas de Arte de $\mathrm{La} \mathrm{Na-}$ ción. Sus trabajos fueron presentados en el Salón de junio de 1925 (Emar). 


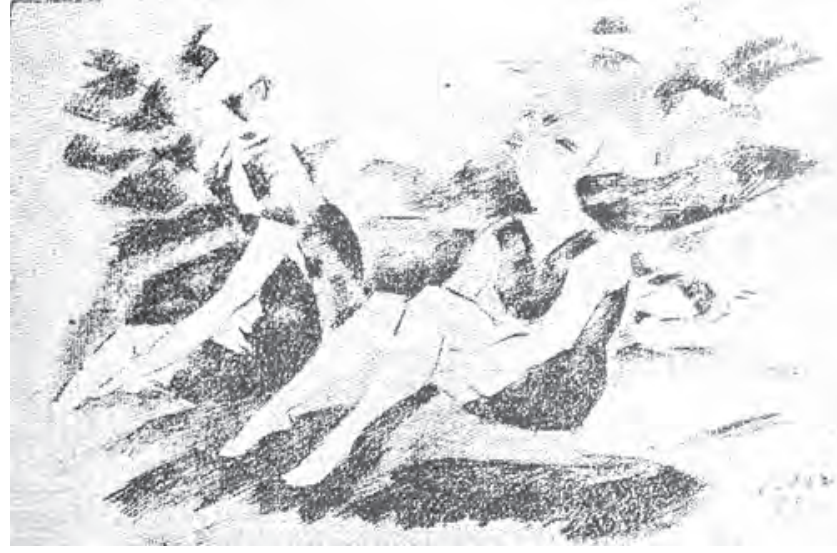

Pablo Vidor. Sin título. n.d. Caballo de Bastos 1.

La imagen es un paisaje con dos figuras, a medio camino entre una representación icónica y una lógica, donde sujeto y entorno no son representados visualmente según una semejanza con el mundo real, sino divididos racionalmente en sus partes constitutivas. Ése es el mismo objetivo tras las representaciones cezannianas que buscan captar, en palabras de Rilke, "Lo contundente, el devenir cosa, la realidad llevada hasta lo indestructible a través de su propia experiencia del objeto [...]» (Bozal, 33). La imagen de Vidor toma de Cézanne el "carácter inorgánico de la obra» (Bürger, 141), que sobrepone el sistema y la estructura por sobre la visualización global del objeto.

Dicho espíritu racionalista se conjuga contradictoriamente en Vidor con una migración de referencias visuales provenientes de la gráfica del expresionismo alemán.

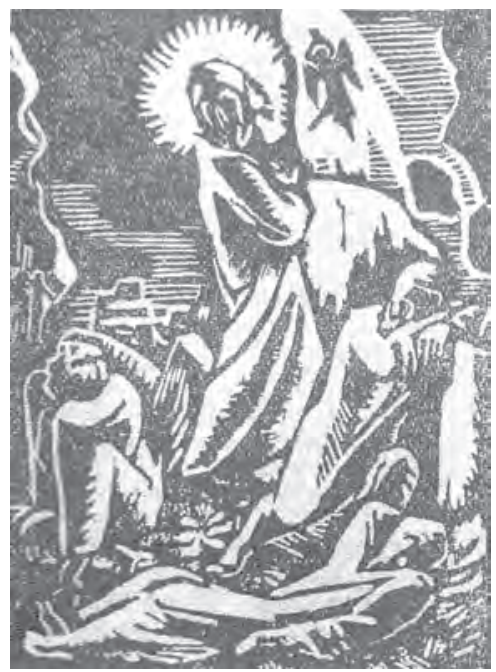

Pablo Vidor. Sin título. n.d. Caballo de Bastos 1 
La xilografía de Andamios representa a un Cristo que no salva ni redime; los hombres a su alrededor están en el suelo y se alejan de su mirada cubriéndose la cara. De manera similar, Emil Nölde y su profeta desgarrado y las distintas representaciones de Cristo de Schmidt-Rottluff retratan el fracaso de la reinstalación de Dios en un mundo secularizado que ya no es regido por él. La xilografía de Vidor hace explícito dicho fracaso en el tratamiento expresivo de la superficie; así, las líneas irregulares y la textura del grano a la vista enfatizan el desgarro de un relato que ha perdido su carácter fundante. Es en esa utilización de la forma como recurso expresivo-dramático donde se hace presente el traspaso desde el expresionismo alemán hacia la obra de Vidor.

Además de las referencias mencionadas, existen dos paradigmas visuales que se seleccionan y conjugan al interior de un retrato realizado por Vidor y difundido en Andamios; el clasicismo y los retratos femeninos de Amadeo Modigliani. En primer lugar, su pintura desencaja del resto de las obras difundidas en la revista; es el retrato de una mujer, altamente realista, que pareciera seguir los preceptos de un arte oficial. La pose de la mujer, específicamente sus manos cruzadas y relajadas, son una traslación de las manos de $L a$ Gioconda, mientras que la posición ladeada de su cabeza, el cuello delgado, la nitidez del dibujo e incluso la expresión del rostro responden a la tradición florentina de Botticelli.

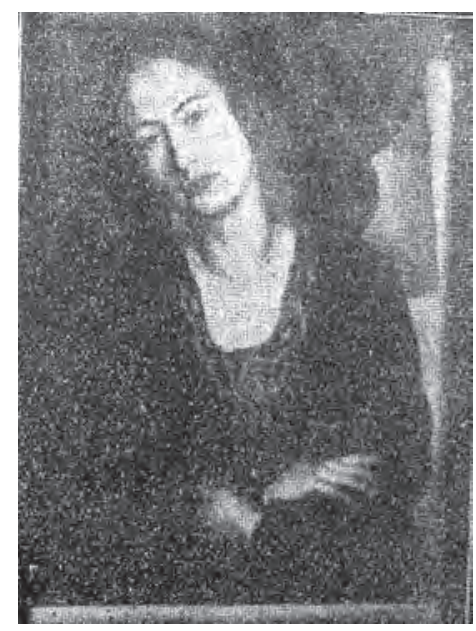

Pablo Vidor. Sin título. n.d. Caballo de Bastos 1.

A pesar de lo anterior, el retrato de Vidor se desplaza leve y casi imperceptiblemente de la tradición clásica, al alargar la figura femenina a un punto límite. Es en esa dilatación casi irreal del rostro y el cuello y en la inclinación exagerada de la cabeza donde emerge la similitud con los retratos femeninos de Modigliani. La semejanza entre ambos artistas reside también en el trabajo bidimensional de los fondos, que, en el caso de Vidor, tienen ciertas reminiscencias cubistas. Así entonces, la particularidad en la conjunción y traslado de ambos paradigmas visuales en la obra reside en que el clasicismo, y con ello el arte oficial, queda desarticulado con sus propios medios, al desplazarse del realismo y servir a la representación de un mundo levemente irreal. 
De ese modo, el conjunto de la obra de Vidor permite la visualización de modelos y lenguajes artísticos disímiles, que más que ser una contradicción responden al espíritu de experimentación, búsqueda y constante renovación que caracteriza al arte nuevo.

Por otra parte, el artista y miembro del grupo Montparnasse Manuel Ortiz de Zárate traslada e instala el abstraccionismo de Kandinsky como paradigma visual de su obra.

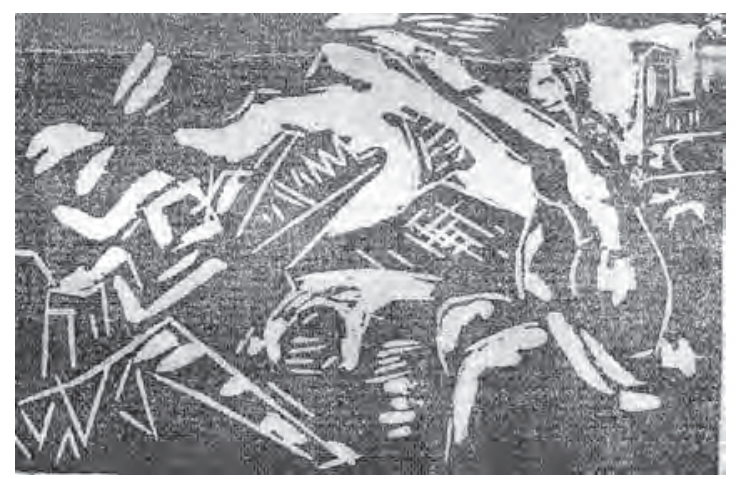

Manuel Ortiz de Zárate. Sin título. n.d. Andamios 1.

La imagen del artista es un grabado que ocupa la portada del primer número de Andamios y que define, por ende, el tipo de arte que será difundido en sus páginas, uno capaz de crear un mundo cerrado de valores puramente plásticos, en el cual el lenguaje artístico explora en torno a sus propios límites y posibilidades. El grabado de Zárate es un juego composicional que incorpora dos figuras humanas, formadas a partir de líneas sueltas, que al mismo tiempo que sirven a la conformación icónica se sostienen como elementos plásticos al interior del espacio creado por la obra. Ortiz de Zárate sigue a Kandinsky en su concepción de la superficie bidimensional, como un espacio que se compone y organiza a partir de los elementos básicos de la pintura: el punto, la línea y el plano (Kandinsky). En la obra del chileno, dichos elementos adquieren un valor doble: por una parte, y leídos como elementos plásticos, son puro significante, exterioridad sígnica, y por otra, desde una lectura icónica, los mismos elementos plásticos adquieren significación si son identificados como representantes icónicos de objetos del mundo natural (en este caso si el conjunto de trazos es leído como «niño» y «hombre»).

De ese modo, la tensión entre elementos plásticos e icónicos en la obra de Ortiz de Zárate, y el valor de dicha tensión como primera portada de Andamios, refleja el enfrentamiento que caracterizará a los primeros años de la vanguardia en Chile, entre dos sistemas de representación: uno cuyo placer estético se basa en la reproducción y reconocimiento de la realidad externa a la obra y otro que, desligado de su deber mimético, transforma la realidad en la obra y explora en las limitaciones y posibilidades de un lenguaje que lucha por alcanzar su autonomía.

Por último, el conjunto de las obras que conforma el discurso visual de Andamios responde a una selección múltiple y contradictoria de poses, gestos y estilos que, en su totalidad, abarcan todo el espectro temporal, desde el primitivismo hasta las vanguardias, «Tanto en el pintor como en el escritor encontramos aquella contradicción general de 
sentido histórico y la intoxicación con la contemporaneidad de todos los estilos históricos que puede compararse con la experiencia de ahogarse y repasar vertiginosamente en un instante la totalidad de la vida» (Praz, 190).

Así, el discurso visual de Andamios refleja en cada una de sus imágenes y referencias visuales los distintos y contradictorios intentos por destruir y crear un nuevo lenguaje: primitivo, expresionista, clásico o bien estructuralista. Ese proceso de renovación perpetua que es el arte nuevo y el derecho al que adscriben sus artistas a ensayar y equivocarse es lo que queda cristalizado en el discurso visual de sus páginas.

\section{DISCURSO ESCRITO}

El grupo Andamios y otras revistas de vanguardia constituyen espacios privilegiados para la apropiación de los ismos europeos, pues por una parte difunden las primeras manifestaciones del arte nuevo y, por otra, educan a un público que no ha sido preparado para la comprensión y valoración de su belleza. En Andamios ese discurso artístico se complementa con un discurso político-social que denuncia principalmente tres hechos: la violencia del Estado hacia los obreros, los conflictos de distribución de la riqueza social y la decadencia del poder en manos de la oligarquía. Tales problemas son denunciados por el grupo como un índice del actual fenómeno de choque del individuo contra la sociedad, cuyo estatismo impide la renovación y la libertad individual, «Es ley inexorable que las instituciones caducan, se estrechan frente a la expansión constante de la vitalidad humana. De ahí que es absurdo pretender crear organismos definitivos para la regulación del desarrollo de la vida social» (Fuentes Vega, Andamios 1, 6).

Dicho discurso político-social se conjuga en Andamios con un discurso artísticovanguardista, que se articulará a su vez desde diferentes perspectivas, que se detallan a continuación.

\section{A) «CON ELLOS O CON NOSOTROS»: POSICIONAMIENTO DENTRO DEL CAMPO}

El grupo Andamios se posiciona en el campo cultural a partir de la definición por diferencia, es decir, mediante la oposición al sistema artístico dominante, que defiende un arte del pasado y cuyas escuelas artísticas no sirven al espíritu del hombre nuevo. Su posición es así radical: nosotros versus ellos; pero ¿quiénes son ellos? «Los literatos cursis, los misoneístas, los poetas a caballo, los anquilosados, los animales de terreras» (Andamios 2, 2). Los poetas de Andamios buscan ser reconocidos como un movimiento de poesía nueva, y para ello hacen explícita su posición desde las antípodas: «No se crea que la actual generación de poetas está alineada como continuación de la anterior. Precisamente su fuerza novedosa estriba en que es diametralmente opuesta» (Caballo de Bastos, 8).

Además, cabe decir que la modificación de las instituciones oficiales se lleva a cabo en Andamios mediante la exhibición del valor y riqueza de ese circuito cultural alternativo. A pesar de que el grupo se defina a sí mismo por oposición al arte oficial, su carácter no es confrontacional y en escasas ocasiones utiliza el humor para criticar a la ideología 
dominante. El método de Andamios es promover los más altos valores artísticos y desde allí legitimar los nuevos imaginarios y sujetos emergentes.

Por otra parte, la conformación del «nosotros» se lleva a cabo con el establecimiento de redes, tanto nacionales como latinoamericanas. En Andamios se difunden las revistas de otros grupos chilenos, Ariel, Claridad y Dínamo, por ejemplo, así como las obras de poetas peruanos y argentinos, y se demuestra simpatía por publicaciones extranjeras como Martín Fierro, "[...] que continúa trayendo puntualmente sus graciosas novedades» (Caballo de Bastos, 8).

Finalmente, es importante la creación de otras instancias de difusión, como la Biblioteca Andamios, las veladas culturales organizadas por la AGP y la creación de una sala de arte libre, que, como instancias de legitimación autónomas, contribuyen a la consolidación de ese «nosotros».

\section{B) LA EDUCACIÓN DE UN PÚBLICO}

Las revistas cumplen con una función educativa al buscar que sus receptores comprendan el nuevo arte como resultado de un largo proceso, que requiere de una nueva sensibilidad y del desarrollo de nuevos códigos estéticos para ser comprendido. En relación a lo anterior, Andamios prepara al público para que reciba y acepte este nuevo arte, mediante la diagramación misma de la revista como collage, y mediante artículos como «Marcel Proust y la novela» y «3 fragmentos del Ulises de Joyce», que entregan las claves para la comprensión del nuevo arte. En ellos se busca ampliar el horizonte de expectativas del lector mediante el quebrantamiento de las normas y de lo que tradicionalmente corresponde a uno u otro género: «La novela puede, pues, admitir todo lo que llama y admite cada desarrollo ordenado de nuestra memoria, cuando toma de nuevo y comenta un tiempo que hemos vivido [...] toda clase de pensamientos, alusiones a todos los conocimientos; ella puede agitar, compulsar todo el espíritu» (Valéry, Andamios 1, 3).

Por otra parte, la creación de las condiciones necesarias para recibir al nuevo arte se realiza con la difusión misma de las obras de vanguardia, cuya selección implica la propagación de cierta calidad literaria. De ese modo Andamios, como guía cultural, defenderá la calidad del nuevo arte en un ambiente que lo desconoce.

\section{C) MOSTRAR, NO DECIR: PROPAGACIÓN DE LAS OBRAS DE VANGUARDIA}

La particularidad del discurso artístico de Andamios reside en que no se encuentra enmarcado por un discurso de grupo o por textos críticos o explicativos de las obras. La revista es más bien una recolección de las distintas manifestaciones de vanguardia, tras lo cual no existe ningún discurso unificador o programático; su único principio, expresado en el manifiesto, es la propagación de la belleza nueva.

Los miembros de Andamios dan a conocer una nueva generación de poetas, que tienen imaginarios acordes a su tiempo y que utilizan nuevos modos de representación. La gran mayoría de los autores que en 1925 fueron seleccionados y difundidos por Anda- 
mios - Neruda, Seguel, Cruchaga Santa María, Rosamel del Valle, Díaz Casanueva, De Rokha- son los que serán incorporados, diez años más tarde, a la Antología de poesía chilena nueva de Anguita y Teitelboim, una de las más selectas y controversiales de la época. Dicha antología resumirá ese primer espíritu de cambio, cuyo valor literario ya había sido reconocido gracias a la labor de estas revistas.

En primer lugar, el creacionismo de Huidobro toma lugar en Andamios con la publicación de su caligrama «Paysage». Ese tipo de poesía visual es, en palabras de Gonzalo Abril, una forma textual nacida de la experiencia tipográfica que sería inconcebible sin la concepción de un espacio sinóptico $(109)^{15}$. «Paysage» requiere así una visión sincrónica por parte del receptor, ya que la unidad del verso no es la línea sino la página completa. Mostrar y decir están tensionados en ese tipo de poesía, pero sobre todo en el caligrama de Huidobro, en el que la materia significante de los signos lingüísticos se toma para dibujar un paisaje, mientras el significado de ellos desdice lo que sus grafos dibujan. En otras palabras, el dibujo, como representación icónica de los objetos del mundo natural ${ }^{16}$, será negado en el nivel del significado de los signos lingüísticos que lo conforman: el árbol no tiene ramas y es más grande que la montaña, el río no lleva peces y la hierba está recién pintada por el poeta; por ende ni dibujo ni lexemas reproducen la realidad sino que crean una propia en el poema.

La reflexión sobre la función creadora del poeta se traslada así al plano de la experimentación formal, y con ello se inserta plenamente «[...] en un proceso de mutua incidencia en el que la reflexión se hace interesada, y la práctica, reflexiva» (Bürger, 12).

En las páginas de Andamios, la experimentación formal y vanguardista de Huidobro se intercala con poemas que responden más bien a una sensibilidad romántica. Esa heterogeneidad da cuenta del estado de transición de la poesía chilena en los años veinte y de la pluralidad de discursos, algunos de ellos vanguardistas - con el uso de un lenguaje no convencional, innovaciones formales e imágenes novedosas- y otros aún ligados a una estética del pasado, más romántica y anecdótica.

En la transición entre ambas estéticas se encuentra «Poema», de Tomás Lago. En él, el sujeto es un alma sombría, que escribe en un escenario de lluvia y niebla para no ser olvidado por la amada. El poema, de temática romántica, es un metatexto acerca del proceso de escritura; ésta no surge desde la inspiración, sino de manera conflictiva, debido a que los signos convencionales del lenguaje se vuelven insuficientes e insatisfactorios para transmitir lo que desea: «[...] ¿qué podría decirte para acercarte a mí?/ rodearte de palabras sin exactitud/con ellas puedo sin duda anticipar la noche» (Andamios 1, 4). La palabra es así un enemigo; instrumento ajeno e inmanejable, que impide la representación directa de la experiencia y lleva al poeta a plasmar en la obra misma, la dificultad de su proceso creador.

El poeta reconoce además su distancia con una generación anterior, "canción de los antiguos poetas que decían doquier/ y sabían el nombre de todas las flores», pero no se inserta tampoco de lleno en una nueva estética, y es en ese vaivén donde reside su incomodidad; es un sujeto de transición que no se adscribe a ningún grupo, pues reconoce el

15 Cabe decir que el caligrama no surgió por primera vez en el siglo XX. La poesía visual ya había sido cultivada por los alejandrinos con el nombre de technopaigna, poemas que sugerían objetos mediante la configuración de versos de diferente longitud (Praz, 10).

16 El ícono es, según Peirce, «[...] un signo que designa a su objeto, en cuanto lo representa o bien imita. Debe tener ciertos rasgos comunes con el objeto, esto es, representa al objeto sobre la base de la semejanza» (Walther). 
desgaste en las palabras de la época precedente, pero no sabe cómo reutilizar este material empobrecido: "Compañeros, aquí está mi abrazo de siempre/ inútil como un anillo vacío».

Anecdóticamente similar, pero alejado del convencionalismo poético, «Innominado» de Pablo de Rokha establece, desde su ausencia de título, la dificultad de nombrar y con ello definir la experiencia a través del lenguaje. El hablante, y único habitante sobre la tierra, se encuentra en un escenario apocalíptico, de niebla, oscuridad y lluvia interminable, cuya mirada abarca al planeta completo, de oriente a occidente: «Tú das al Universo este color rodante/ y este rumor violeta cruzado de cigarras;/... siento que se ha trizado la curva de la tierra/ al peso colosal de tu pie entristecido/...y una gran paloma negra se desmaya en las arboladuras del occidente» (Andamios 1, 6).

«Innominado» es una propuesta espacial, cuyo valor no reside en la descripción de formas ya conocidas, sino en la construcción de un espacio jamás preexistente, que se funda a partir de contrastes que unen elementos distantes y configuran imágenes insólitas, "Mis pájaros de alambre triste/ se ahogan en tus crepúsculos,/ y yo gimo mamando nieblas/...las lágrimas innumerables/ extienden una cortina de pájaros agonizantes».

El poeta es capaz de visibilizar, como testigo único de la caída, un mundo completo en ruinas que se desploma, no por la ausencia de un Dios, sino por el vacío de la hermana, amiga y esposa. Lo «innominado», incapaz de ser nombrado y acotado en un título, es aquel intersticio entre vida y muerte, creación y destrucción, que requiere figuras contrastantes e imágenes tensionadas para poder ser visualizado a manos del único testigo de la caída, el poeta.

Por otra parte, la figura de Pablo Neruda es homenajeada por el grupo Andamios, que se refiere a él como el mejor poeta de Chile y le dedica varias páginas a la difusión de sus versos $^{17}$. Su poesía, eminentemente visual, es una condensación simplificada y densa de imágenes, que, como afirma Malvar sobre el poema moderno, «[...] exige del lector un trabajo complementario de reconstrucción, de sensibilidad casi paralelo al autor» (Lizama 31). Esa reconstrucción del objeto visual en palabras requiere, como afirma Zaldívar, una serie de cambios significativos, «[...] en el transcurso del recorrido que va desde la construcción del objeto visual dentro del sujeto, utilizando para dicha reconstrucción una imagen espacial, a la reconstrucción del objeto visual, fuera del sujeto, utilizando para ello un medio diferente, la palabra, es decir, un medio que se materializa a través de una dimensión temporal» $(21)^{18}$.

En «Poesía escrita de noche» existe un desborde de materialidades que se anexan unas a otras para conformar un dibujo mental inusitado. En el poema, la propuesta visual de cada uno de los versos está condensada y cerrada de tal manera que impide su conexión con el verso siguiente, «el día es de fuego y se apuntala en sus colores/ el mar lleno de trapos verdes sus salivas murmullan yo soy el mar/ el movimiento atraído la inquieta caja/ tengo fresca el alma con todas mis respiraciones / ahí sofoco al lado de las noches antárticas» (Caballo de Bastos, 5).

17 Cabe decir que Pablo Neruda fue codirector de Caballo de Bastos, publicación en la que aparecen sus poemas.

18 Este procedimiento es denominado ekphrasis, «recurso literario que encierra la metáfora de la dificultad permanente del signo artístico para representar la realidad. Este recurso realizado con fines estéticos pretende recrear y representar, por medio del lenguaje y sobre la hoja de papel, un objeto del arte plástico» (Zaldívar, 19). 
Ese desborde visual es un recorrido por todos los tiempos y espacios, por todas las materias y sensaciones, lo que equivale a «[...] la experiencia de ahogarse y repasar vertiginosamente en un instante la totalidad de la vida» (Praz, 190). Esa simultaneidad se construye en el poema por una dislocación temporal, que anula el pretérito y lleva a leer cada verso como un primero. El tiempo se configura así, una y otra vez desde el presente, pues en él no existe conciencia de ninguna anterioridad ni por ende profundidad temporal, «mis alas absorben como el pabellón de un parque con olvido/ amanecen los puertos como herraduras abandonadas/ ay me sorprendo canto en la carpa delirante/ como un equilibridista enamorado o el primer pescador/ pobre hombre que aíslas temblando como una gota».

La superposición de imagen tras imagen permite poner en paréntesis la temporalidad de la palabra, en un «[...] cuadrado de tiempo completamente inmóvil» y construir el objeto visual desde la espacialidad y simultaneidad que es propia a la imagen. Esa construcción desde múltiples perspectivas acerca la mirada nerudiana a la yuxtaposición de las pinturas cubistas, pues en ambas la visualización del objeto se logra a partir de una rotación continua que exhibe todos sus perfiles de una sola vez, "[...] donde la misma forma aparece mezclada con otras, donde la misma letra del alfabeto o el mismo perfil surge inesperadamente aquí y allá en una rotación continua [...]»(Praz, 191).

Por su parte, Winétt de Rokha representa en «Rueda» la experiencia ambigua y contradictoria de aquel sujeto situado en un estado de transición a la modernidad. El poema comienza en un tiempo primero, que no tiene conciencia de sí mismo, donde mujer y naturaleza están en armonía y forman parte de una misma unidad, "Fue en el tiempo inmóvil e inalterable/ cuando yo era como las manzanas» (Andamios 2, 5). Este primer estadio se ve interrumpido con la llegada de una "[...] canción de caminos de bronce»; que se repite como todas las cosas del universo; «las tempestades, las sombras, la vida», y que sin embargo difiere de ellas, pues en su repetición, la canción sigue siendo nueva. Así, los caminos de bronce que se edifican — metáfora del ser moderno en la ciudad- equivalen a aquel mundo de fantasía e ilusión que presenta siempre-lo-mismo con la forma de lo-siempre-nuevo (Picó, 26) y así, la ilusión por un cambio real, que se espera con "pupilas de carbón de piedra», termina por convertir la linealidad del tiempo moderno en un tiempo cíclico, que al negar el cambio y el progreso desarticula el proyecto entero de la modernidad.

Por otro lado, la destrucción que trae consigo la creación moderna y la separación entre el presente y un pasado irrecuperable es un tema que muchos de los poetas de $A n$ damios interiorizan con la metáfora de la pérdida de una mujer. En «Estatuas de niebla», Gerardo Seguel se refugia en el recuerdo de un pasado - identificado con su vida en el pueblo- que se olvida y rememora con nostalgia, «PUEBLO mío canción de la infancia HERMANA mía que me escribes pidiendo cartas largas y frente a todo tú LEMNA crepuscular detienes el vuelo de los pájaros» (Andamios 1,8). De manera similar Cruchaga Santa María, en su poema "Ceniza", anticipa la muerte del pueblo con la muerte de su amiga, siendo las figuras mujer-pueblo-pasado, una tríada utilizada por éste y otros poetas para contrastar y tensionar las imágenes de un estado anterior, con la actual desolación del sujeto.

Cabe decir que en los autores mencionados, la temática de la destrucción moderna refiere tanto a la pérdida física de un pueblo como a la crisis de fundamentos. Así, mientras Alejandro Gutiérrez se lamenta porque «Las estrellas que alumbran tu ciudad me están 
apedreando las pupilas» (Andamios 1, 9), Eric Gouzy expresará un sentimiento de orfandad teológica y de soledad metafísica, al afirmar el vacío de una ausencia reciente: «Estoy tan solo en mi soledad-que interrogo a las vidas si existo-Debo ser un satélite que gime en su orfandad-al mirar el pie roto de un Cristo» (Caballo de Bastos, 8). En todos ellos, el único estandarte frente a la destrucción moderna, física o metafísica, será la lucha contra el olvido, el abrir la caja de recuerdos y sobrevivir con la memoria.

\section{LA APERTURA MÁXIMA DE ANDAMIOS}

El grupo Andamios se instala en 1925 en Chile, en un campo cultural rígido, dominado por una oligarquía en decadencia, cuyas instituciones - tanto políticas como artísticasse estrecharon progresivamente frente a un dinamismo humano pujante. La década del veinte se caracterizará por el enfrentamiento entre esos dos grupos, que en términos artísticos representan dos estéticas distintas: un arte mimético-pasivo, que reproduce el mundo en la obra, y un arte nuevo, que, unido a la praxis vital, reflexiona en torno al sentido, naturaleza y función del arte al interior de la misma práctica artística. Esas dos estéticas definirán un campo cultural polarizado entre un nosotros y un ellos, y en esa disputa la labor de la AGP y del grupo Andamios resulta fundamental, en cuanto enfrenta al poder dominante en todas sus manifestaciones: al mismo tiempo que busca resolver el problema de la educación con la propuesta de una reforma educacional — que introduce a los grupos medios y modifica el campo cultural-, funda el ambiente propicio para la difusión y posicionamiento de las vanguardias artísticas en Chile.

El grupo Andamios, conjuntamente con la AGP, sitúan la discusión sobre el arte nuevo y la difunden masivamente, no sólo a través de publicaciones, sino también con la creación de una biblioteca, hogares sociales y veladas culturales. La revista misma es una instancia a través de la cual la Asociación logra hacer confluir su discurso pedagógico y artístico-vanguardista, pues presenta el arte nuevo y al hacerlo entrega las claves para su comprensión en la morfología misma de la revista como collage. Así, Andamios prepara cognitivamente a un público que, a mediados de los veinte, no había sido capacitado para la comprensión de este nuevo arte, además de lo cual, con una propuesta estético-ideológica desafiante, modifica el gusto de sus lectores dentro de un campo cultural homogéneo.

Andamios se configura así como una revista de vanguardia, tanto por los contenidos que presenta, como por su trabajo editorial reflexivo. La revista se piensa a sí misma como objeto de mediación y tensiona ese carácter en la disposición discontinua y heterogénea de sus discursos, los que literalmente se recolectan y ponen sobre la página. Así, el uso de tipografías y tamaños distintos en cada uno de ellos hace manifiesta la intención de definir a Andamios desde su posición de agente intermediario que recoge, selecciona y hace visible el discurso plural y heterogéneo del arte en la década del veinte.

Asimismo, la selección de imágenes de Andamios refleja una máxima diversidad de referencias visuales, que abarcan un espectro espacial y temporal completo; desde el primitivismo a los ismos europeos y desde Oriente a Occidente. Ese aparentemente contradictorio conjunto de imágenes logra enfrentar con fuerza a un discurso monológico y hegemónico, mediante un beligerante «dialogismo visual» que pone en contacto elemen- 
tos aparentemente distanciados, creando imágenes insólitas que expresan, en el mismo diálogo de sus referencias visuales, el conflicto estético interno del campo artístico y literario. Así, la irrupción de elementos meramente plásticos al interior de un sistema de representación icónico o la desarticulación del clasicismo, y con ello del arte oficial, a favor de una representación subjetiva revelan, en la superficie misma de la imagen, el conflicto irresuelto entre dos estéticas, tradición y modernidad, que se traduce a su vez en un enfrentamiento concreto entre un nosotros y un ellos.

Las imágenes seleccionadas por Andamios, que provienen en su mayoría del grupo Montparnasse, permiten la representación de nuevos actores sociales y la conformación de un «nosotros» cada vez más definido, que se consolida gracias al establecimiento de redes nacionales y latinoamericanas que integran la labor de Andamios a América y dan cuenta del dinamismo cultural del continente.

Del mismo modo, Andamios hace circular a los nuevos poetas de la década del veinte, que revelan el momento mismo de cambio entre voces antiguas y nuevas. Ese momento de transición se evidencia en la heterogeneidad del discurso poético de la revista, que se desplaza desde el vanguardismo de Huidobro — con innovaciones formales e imágenes novedosas-, al romanticismo más anecdótico de Tomás Lago.

Sin embargo, en la mayoría de esas nuevas voces, el proceso de incorporación y apropiación de los planteamientos vanguardistas europeos se lleva a cabo de manera activa; en Winnét de Rokha, la mirada crítica a la modernidad trae consigo el regreso de un tiempo cíclico que rompe con la idea de avance y progreso; por su parte, Pablo de Rokha expande las posibilidades del poema en una interpenetración espacial y temporal que reconfigura las posibilidades de representación en poesía, y finalmente, el desborde material de Neruda, en su yuxtaposición de imagen tras imagen, abre la mirada del objeto hacia una rotación infinita y enriquecedora.

En todos esos poetas de Andamios, y a pesar de sus distintas estéticas, existe una incomodidad común, que deriva de situarse en un momento de transición entre un pasado con el que ya no se identifican y una modernidad que sienten ajena y amenazante.

Finalmente, el valor particular del grupo Andamios reside en su triple discurso, político, educativo y artístico, que modifica el campo cultural mediante la difusión de las obras de vanguardia y que, a su vez, modifica las condiciones socioculturales para la aceptación del arte nuevo. La ausencia de un discurso unificador entre los distintos textos de Andamios y la manifestación de un único principio - propagar la belleza nuevapermite visualizar esa época de cambio, con todas sus incomodidades, subjetividades y contradicciones.

De ese modo, la revista Andamios toma la forma de un collage discontinuo e irresuelto, que presenta asimismo un arte contradictorio y múltiple: imágenes que abarcan todos los tiempos y espacialidades y una poesía que se desplaza desde lo romántico a lo vanguardista, tanto con figuras desgastadas como con imágenes insólitas. Esta pluralidad máxima, de tiempos, espacios, escuelas y referencias, es respetada por Andamios con la presentación irresuelta y discontinua de las voces divergentes que constituyen la vanguardia chilena en la década del veinte. 


\section{REFERENCIAS}

Andamios 1 y 2 (1925). Medio impreso.

Abril, Gonzalo. Cortar y pegar: La fragmentación visual en los orígenes del texto informativo. Madrid: Cátedra, 2003. Medio impreso.

Altamirano, Carlos y Beatriz Sarlo. Literatura/Sociedad. Buenos Aires: Hachette, 1984. Medio impreso.

Bosi, Alfredo. «La parábola de las vanguardias latinoamericanas». Las vanguardias latinoamericanas. Coord. Jorge Schwartz. México: Fondo de Cultura, 2002. Medio impreso.

Bourdieu, Pierre. Las reglas del arte. Génesis y estructura del campo literario. Barcelona: Anagrama, 1995. Medio impreso.

Bozal, Valeriano. Los primeros diez años: 1900-1910, los orígenes del arte contemporáneo. Madrid: Visor, 1991. Medio impreso.

Bürger, Peter. Teoría de la vanguardia. Barcelona: Península, 1987. Medio impreso.

Cundy, David. "Marinetti and Italian Futurist Typography». Art Journal 41 (1981). 349-352. Medio impreso.

Emar, Jean. Notas de Arte (Jean Emar en La Nación, 1923-1927). Santiago: Dibam/RIL Editores, 2003. Medio impreso.

Elderfield, John. El Fauvismo. Madrid: Alianza Editorial, 1983. Medio impreso.

Genette, Gérard. Umbrales. México: Siglo XXI, 2001. Medio impreso.

Greimas, J. A. "Semiótica Figurativa y Semiótica Plástica». Figuras y estrategias: en torno a una semiótica de lo visual. México: Siglo XXI, 1999. 78-112. Medio impreso.

Harris, Neil. "Definitions of bibliography, and in particular of the variety called Analytical». Analytical bibliography: an alternative prospectus. Lyon: Institut d'histoire du livre, 2004. Medio impreso.

Kandinsky, Wassily. Punto y línea sobre el plano. Buenos Aires: Nueva Visión, 1969. Medio impreso.

Lizama, Patricio. "Estudio». Notas de Arte (Jean Emar en La Nación, 1923-1927). Santiago: Dibam/RIL Editores, 2003. 9-43. Medio impreso.

Moraña, Mabel. «Revistas culturales y mediación letrada en América Latina». Crítica Impura. Madrid: Iberoamericana-Vervuert, 2004. 239-246. Medio impreso.

Paz, Octavio. «Rupturas y restauraciones». El paseante 23-25 (1985). Medio impreso.

Praz, Mario. Mnemosyne: El paralelismo entre la literatura y las artes visuales. Madrid: Taurus, 1979. Medio impreso.

Picó, Joseph. Modernidad y postmodernidad. Barcelona: Alianza Editorial, 1988. Medio impreso.

Read, Herbert Edward. La pintura moderna. México-Buenos Aires: Hermes, 1964. Medio impreso.

Santos, Danilo. "Las vanguardias en la década del veinte: La Asociación General de Profesores y Nuevos Rumbos». Taller de Letras 27 (1999). 149-158. Medio impreso.

Sosnowski, Saúl (comp.). La cultura de un siglo: América Latina en sus revistas. Madrid: Alianza, 1999. Medio impreso.

Subercaseaux, Bernardo. Genealogía de la vanguardia en Chile. (La década del centenario). Santiago: Lom, 1998. Medio impreso. 
Vergara, Sergio. Vanguardia literaria. Ruptura y restauración en los años 30. Concepción: Universidad de Concepción, 1994. Medio impreso.

Warburg, Aby. Atlas Mnemosyne. Madrid: Akal, 2010. Medio impreso. El renacimiento del paganismo: Aportaciones a la historia cultural del Renacimiento europeo. Madrid: Alianza Editorial, 2005. Medio impreso.

Walther, Elizabeth. Teoría general de los signos: introducción a los fundamentos de la semiótica. Santiago: Dolmen, 1994. Medio impreso.

Zaldívar, María Inés. La mirada erótica en algunos poemas de Gonzalo Millán y Ana Rosetti. Santiago: Chile Red Internacional del Libro, 1998. Medio impreso.

Recepción: 15 de marzo de 2011 Aceptación: 4 de septiembre de 2011 